\title{
6
}

\section{Just a dream? The struggle for national resource sovereignty and oil infrastructure development along Timor-Leste's south coast ${ }^{1}$}

\author{
Judith M. Bovensiepen
}

In May 2015, I was driving with a friend through Timor-Leste's capital, Dili. It was around lunchtime and the streets were buzzing with traffic, with cars entering the road from all sides and in all directions, incessantly honking and often squeezing into a fourth or fifth lane on the threelane road. We got stuck right in front of Timor Plaza - a relatively new multi-storey shopping mall that, despite high prices, attracts many visitors every day. A mikrolet (minibus) stopped in front of us that carried almost double the passengers it was built for, with quite a few young men hanging on outside. Loud Indonesian pop music was blasting from the speakers. It looked like most other mikrolets in Dili. However, three words stood

\footnotetext{
1 This article is based on research carried out in collaboration with, and with the support of, Monis Filipe, Flaviano Freitas and Evya do Carmo; they do not necessarily share the views expressed in this article. This research is based on seven months of fieldwork in Timor-Leste carried out in 2015 and 2016, which involved interviews with government officials, members of the oil industry, civil society and the 'affected community' of the Tasi Mane project in Suai and Betano. All interviews are anonymised. I would also like to thank all the participants of the University of Kent workshop 'Visions of the Future in Timor-Leste' for their helpful feedback, as well as Bernardo Almeida for his comments on this chapter. The research was funded by the Economic and Social Research Council (grant no. ES/L010232/1).
} 
out that were written in gigantic pink letters in English across the back: 'just a dream'. My companion turned to me, let out a loud laugh and said, 'the perfect metaphor for the Tasi Mane project - really just a dream'.

The Tasi Mane project is a state-led development scheme, aimed at developing the south coast through heavy investment in infrastructure, industry and tourism. The project envisages the development of three industrial clusters on the thinly populated south coast of the country (La'o Hamutuk 2011; SDP 2011; TimorGap 2015; see Figure 6.1). Its centrepiece is the construction of petroleum infrastructure with an oil refinery and a liquefied natural gas (LNG) plant to be completed by 2020. Its goal, as a respondent who is one of the main drivers behind its implementation explained, is to 'unleash the potential of the south coast' and to turn the south into the 'power house' of the country. The Tasi Mane project is one articulation of growing resource nationalism in Timor-Leste, the government's endeavour to assert control over the natural resources in its own territory inspired by a sense that East Timorese should benefit from profits derived from their own resources. The project is controversial and has been strongly criticised by civil society groups. However, scepticism among foreign observers has also been met by an increasing sense of frustration in the country about what is seen as a patronising attitude by outsiders towards attempts to realise plans for a prosperous future.

Plans to build a large petroleum infrastructure are not the only manifestations of resource nationalism; another instance was the government's bold strategy to try and force Australia to re-enter negotiations with regards to the maritime boundary between both countries. TimorLeste's largest oil and gas reserves are located offshore, including the Sunrise and Troubadour gas and condensate fields, collectively known as Greater Sunrise, which lie about $450 \mathrm{~km}$ north of Australia and $150 \mathrm{~km}$ southeast of Timor-Leste. According to the Law of the Sea's median line principle, the majority of the reserves would belong to Timor-Leste, but, until recently, Australia refused to negotiate maritime boundaries and had proposed a resource-sharing agreement that would provide Timor-Leste with only 50 per cent.

Immediately before Timor-Leste regained independence in 2002, Australia withdrew from a key aspect of the United Nations Convention on the Law of the Sea in order to avoid the juridical determination of the border between both countries. In January 2015, the East Timorese 
Government launched a series of campaigns to garner support for a median line agreement and triggered a non-binding but compulsory conciliation process (Leach 2018). In March 2018, Timor-Leste secured a landmark agreement, settling the Australia-Timor-Leste maritime border along the median line and agreeing on a fairer Greater Sunrise revenue split. The decision was widely celebrated as an unprecedented breakthrough. ${ }^{2}$

This chapter examines some of the dynamics and effects of resource nationalism in Timor-Leste. More specifically, it looks at the relationship between state-led onshore oil infrastructure development plans (the Tasi Mane project) and the desire for full national resource sovereignty through boundary negotiations with Australia. While it has been argued that these two are in principle separate issues, this chapter illustrates that resource nationalism tends to conflate the issue of boundaries and the issue of infrastructure. This conflation must be understood in the context of two forms of domination: first of all, resource nationalism gains traction through 'occidentalism' - a term developed by Coronil (1997: 14) to describe the 'stereotypical representations of cultural difference', which form part of 'the West's self-fashioning as an imperial power'. Negative stereotypes about Timor-Leste's supposed inability to govern itself, and presumed inevitable 'squandering' of resources, form part of the reproduction of geopolitical power asymmetries. These are arguments that have been used to delegitimise Timor-Leste's legitimate claims to full sovereignty.

Second, resource nationalism is a fertile ground for what Reyna and Behrends (2008: 11) have called 'crude domination' - namely, the 'struggles to dominate the flow of value produced by oil' (ibid.: 15), which can be examined by paying attention to how different groups (local, national and transnational) seek to assert their dominance in the struggle over resources. As will be examined later in this chapter with regards to the Tasi Mane project, nationalist arguments about resource sovereignty are used by politicians and members of the oil industry in order to stifle internal critique of ongoing development plans. While occidentalist representations intensify nationalist sentiments, these very nationalist

2 This article was written in 2015 and revised in 2016 and hence does not include a detailed discussion of the most recent developments. The focus is on the campaign to re-enter boundary negotiations with Australia as an expression of resource nationalism, rather than on the outcome of these negotiations. 
arguments (that derive from legitimate grievances) in turn enable 'crude domination' by presenting those who criticise current infrastructure development projects as 'anti-nationalist'.

\section{Resource nationalism}

In the Timor-Leste Strategic Development Plan 2011-2030 (henceforth SDP), launched in 2011, the Sixth Constitutional Government of Timor-Leste formulated a clear vision for the future. As one member of this government told me, this vision is one where Timor-Leste will be an internationally recognised upper-middle-income country, with transparent institutions and a diversified economy. The SDP is a key policy document that is seen to have been developed and designed with the strong personal involvement by the former prime minister Xanana Gusmáo. The document includes plans to improve education and health, and develop cultural heritage as well as Timor-Leste's oil and non-oil economies. It also contains plans for the development of human resources for the petroleum industry, for the establishment of a national petroleum company and for the so-called Tasi Mane project (SDP 2011: 136-138). These ambitious development plans by the government are (at least at this point) largely to be financed by oil revenue from the Timor-Leste Petroleum Fund. The plans were made despite warnings that at current spending levels, the Petroleum Fund will be exhausted by about 2025 (La'o Hamutuk 2015). ${ }^{3}$

In Suai, the planned scheme stipulates building a supply base including a port, an international airport and a crocodile farm (La'o Hamutuk 2011). Furthermore, the Ministry for Petroleum and Mineral Resources has been reviewing business plans that include carpentry and forestry projects; a cattle slaughterhouse; and discussions with an Australian cruise ship company, which is thinking of bringing up to 2,000 tourists at a time to Suai, who could then be taken by helicopter to interesting tourist sites throughout the country, such as the Marobo hot springs in the west of Timor-Leste.

3 Revenues from Greater Sunrise are likely to extend this prediction, though La'o Hamutuk (2018) has recently pointed out that 'Even according to the most optimistic credible projections, Sunrise will only finance Timor-Leste's state and economy for less than one generation'. 


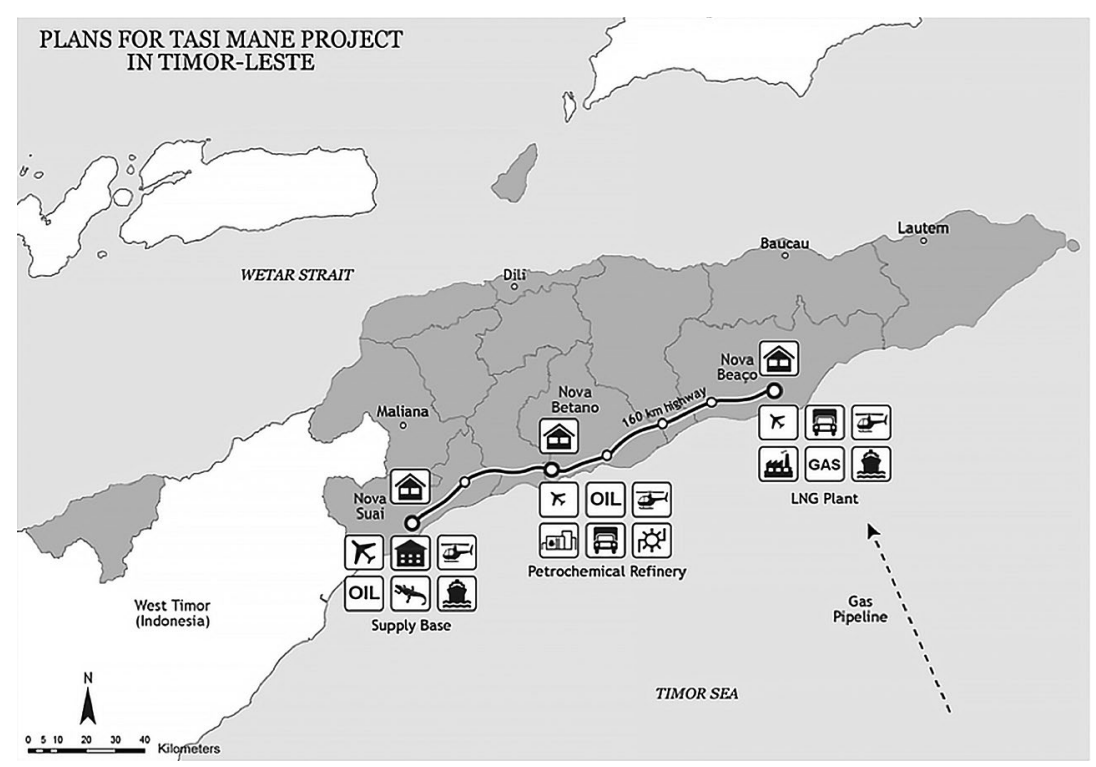

Figure 6.1. Plans for the Tasi Mane project.

Source: Map by Helder Bento, used with permission.

In Betano, there is supposed to be an oil refinery and a petrochemical plant. In Beaço, plans include an industrial complex and an LNG plant, and marine facilities for offloading goods. The refinery will provide fuels, such as diesel, gasoline and jet fuel. There are plans for three new cities Nova Suai, Nova Betano and Nova Beaço - to administer these projects, and a large, $160 \mathrm{~km}$ four-lane highway connecting these three industrial clusters (La’o Hamutuk 2011; SDP 2011; TimorGap 2015).

The Tasi Mane project involves resettlement of people who are living in the affected areas, as well as the 'liberation' (as it is called) of vast stretches of land for the construction of the oil and gas infrastructure. Residents living in areas, affected by the construction work are to receive financial compensation for their land (see Bovensiepen and Meitzner Yoder 2018; Crespi and Guillaud 2018). At the time of writing, the identification of land and compensation payments were almost complete in Suai, and land to be 'liberated' was identified in Betano; least progress had been made in Beaço, where the pipeline from Greater Sunrise is to lead to. A series of community meetings had been held in all three locations, so-called 'socialisations', in order to inform the affected population about the process. 
In 2015, I took part in a series of these 'socialisations' in Suai and Betano. During the speeches given by members of government and representatives from the oil industry, the language of nationalism, resistance and sacrifice were prominently used to motivate the participants to give their support (and land) to the Tasi Mane project. The same was true during mediations to resolve land conflict, and consultations organised to provide training and information to community members about how to deal with the large sums of money they had received as 'compensation' for their land.

The speech during one of these 'socialisations' by the subdistrict administrator I mentioned in the Introduction was a clear example of this. Through the Tasi Mane project, he said, Timor-Leste will move 'out of darkness, into light' (husi nakukun, ba naroman). He repeated this phrase again and again throughout the speech and connected it to the struggle for Timor-Leste's self-determination. The past was the darkness and the future will bring light. 'This is what we fought for during the independence struggle', he continued. 'The darkness is now behind us, and the light ahead of us.' At the time of Portuguese colonialism, Timor went 'from darkness to darkness' (busi nakukun ba nakukun). But since independence has been achieved, since there has been self-determination, 'everything has been moving forward' (buat hotu lao ba oin). The administrator told the audience that they needed to give something up, so that the country could go ahead and develop, so that the country could move out of darkness and into the light. His speech was greeted by enthusiastic cheers from the audience.

After the subdistrict administrator's speech, it was the turn of a senior member of the national oil company TimorGap. First, he led a short prayer, saying, 'We pray that this pipeline project will be successful'. Then he expressed special respect to former resistance fighters (veteranos). References to veterans and to the resistance struggle against Indonesia were a prominent feature of many of the speeches during the 'socialisation' events I attended, and often individual veterans were invited to sit on the front podium to show their support for the project. During these events, arguments about sovereignty and oil infrastructure construction were treated as the same issue.

More specifically, oil and gas infrastructure development was represented as an inherent part of the country's long history of resistance against foreign occupation, and this also emerged in interviews I carried out with a number of politicians. One high-level politician involved in the 
implementation of the Tasi Mane project argued that the development along the south coast was part of achieving independence (ukun rasik aan) - it was 'through development that people are liberated'. Another interviewee and member of the previous government argued along similar lines when he said:

Claims to the oil of [the] Timor Sea is [a] normal ambition for countries where the oil companies call the shot $[\mathrm{s}]$... if Australia chooses to continue with the illegal 'occupation' of the Timor Sea, [it is] stealing the oil from the rightful owners.

The struggle for independence was seen as incomplete until the country's borders are clearly defined. A respondent from Timor-Leste's Ministry for Petroleum and Mineral Resources maintained that the 'struggle for a pipeline' was a continuation of the resistance struggle, operating 'on three fronts'. Whereas resistance against Indonesia was fought on 'clandestine, diplomatic and military fronts', the 'struggle for Greater Sunrise' was fought on 'technical, legal and commercial fronts'.

I frequently asked research participants how and when the idea of the Tasi Mane project emerged. The most common response was that this idea emerged long before Timor-Leste regained independence, during the resistance struggle against Indonesia. The idea of building a pipeline from Greater Sunrise oil and gas fields to the south coast of Timor-Leste was one of the most important aspects of the Tasi Mane project mentioned. One respondent suggested that this idea of a pipeline came to former resistance leader Xanana Gusmão in a dream while hiding from the Indonesian military. Others said the idea to develop the south coast was conceived by members of the 'diplomatic resistance' who were living in Australia during the Indonesian occupation. Those who suggested that the vision of south coast development and the pipeline arose during the resistance also indicated that it was and essentially is still a part of resistance against foreign domination, and economic and political dependency on foreigners, including donors.

Concrete historical experiences drive the vision of resource sovereignty, especially with regards to the boundary with Australia. In scheming for the oil and gas reserves in the Timor Sea, Australia employed 'win-atall-costs tactics' (McGrath 2014: 2) - for example, ordering raids (in the interests of 'national security') against a Canberra lawyer who was investigating allegations that Australia had been spying on TimorLeste to gain a commercial advantage in the negotiations about Greater 
Sunrise. Calls for the permanent delimitation of maritime boundaries with Australia initially came from the activist community in TimorLeste, which had been criticising Australia's stance long before the issue received such widespread national attention. Activists pointed to the interconnections between Australia's acknowledgement of Indonesia's illegal occupation and its entering into negotiation with Indonesia over Timor's oil and gas (see McGrath 2017). Australia was the only western country to recognise Indonesia's annexation of East Timor, but even prior to Indonesia's invasion, the Whitlam Government used oil and gas reserves in the Timor Sea as the main reason to plead in favour of East Timor's 'integration' into Indonesia, arguing that it was easier to negotiate with Indonesia than with Portugal about a seabed border (Aditjondro 1999: 18). In 2015, a series of campaigns and protests were launched against Australia's refusal to negotiate a permanent maritime boundary. Arguments made by the activist community were appropriated and used to argue not just for boundary negotiations, but also in favour of Tasi Mane onshore infrastructure plans. Advocates of the project drew on the sentiments and frustrations that had built up around the boundary.

In the Introduction to this volume, I made the case that the negative consequences of oil dependency are more severe in some countries than in others. Gledhill (2008: 57) has argued that (at the time of his writing), several Latin American countries could mitigate the negative effects precisely through policies of resource nationalism, expressed in the notion that 'our oil belongs to the people'. This notion connected calls for national resource sovereignty to campaigns for social justice. In these cases, nationalist imaginaries successfully managed to ward off arguments that development can only go ahead if all remaining barriers to foreign investment are abandoned. The situation in Timor-Leste is clearly different - nationalist arguments are not used to protect the economy from market liberalisation; in the implementation of the Tasi Mane project, nationalist arguments seem to displace social justice concerns, rather that connect with them.

\section{Occidentalism}

In 2013, an incident occurred that caused a lot of consternation in government circles. A member of staff at the National Petroleum Authority (ANP [Autoridade Nacional do Petróleo]) of Timor-Leste is said to have 
thrown the Field Development Plan for the Greater Sunrise oil and gas fields back into a car driven by representatives of Woodside Petroleum, the Australian oil and gas company. The representatives had gone to the ANP offices to present what were supposed to be Woodside's options for the safest, technically possible and economically most viable way of developing Greater Sunrise. However, to the disappointment of the East Timorese interlocutors, Woodside only came up with two options: first, a floating LNG platform; and second, a pipeline to Darwin. What they had left out of the Field Development Plan was the option for a pipeline from Greater Sunrise to Timor-Leste's south coast.

Members of Timor-Leste's government and of the oil and gas industry frequently recounted the 'document-throwing' incident to me; the incident had clearly provoked intense emotions of anger and frustration. I was told that when the ANP representatives noticed that Woodside's Field Development Plan did not contain the Timor pipeline option, they tried to stall the meeting. When the Woodside staff realised what was going on, they simply left the document at the ANP offices and walked out of the meeting room. They are said to have moved quickly out of the building, trying to reach their car. After their sudden exit from the offices, the Woodside representatives could not find their car, and walked distraught up and down the car park. Staff at ANP saw this as an opportunity: a security guard was sent to follow the Woodside representatives and hand the documents back. As one of my respondents recounted, 'there was "shuffling", the car was right in front of the building, but they [Woodside staff] could not find it'. The local media was present to film the entire incident. He continued:

So for us it was 'the ancestors are helping us ... the past people are blinding these guys'. And then we threw the books back into their car. And it was all over the media. And it was a big drama. So they [Woodside] left. Officially they could not say [anything] because we got offended ... But we understood that they were just going to push us aside.

I heard several different variations of this incident. However, most accounts stressed how insulting Woodside Petroleum's behaviour was, and how offensive their position was, to not include the option for a pipeline from Greater Sunrise to Timor-Leste's shores in their Field Development Plan. And yet there was another political aspect to the dispute: the incident took place just before an important deadline. There had been an agreement that Timor-Leste or Australia had the right to suspend the controversial CMATS Treaty (Certain Maritime Arrangements in the Timor Sea - 
a treaty that instated a 50/50 resource-sharing agreement for upstream revenues from Greater Sunrise) if no Greater Sunrise development plan had been approved by 23 February 2013 (La’o Hamutuk 2016; Leach 2013). One commentator I spoke to argued that by throwing the document back into the car, Timor-Leste made a first step towards forcing renegotiations with Australia over Greater Sunrise, as it meant refusing to accept the proposals for the Greater Sunrise development. If there was no development plan, negotiations could be opened again. In April 2013, there was a request by the Timor-Leste Government to invalidate the CMATS agreement, because Australia had bugged the East Timorese prime minister's meeting room during the negotiations - a case that was later taken for arbitration to The Hague (for details outlining the history of CMATS and other agreements, see La'o Hamutuk 2016). ${ }^{4}$

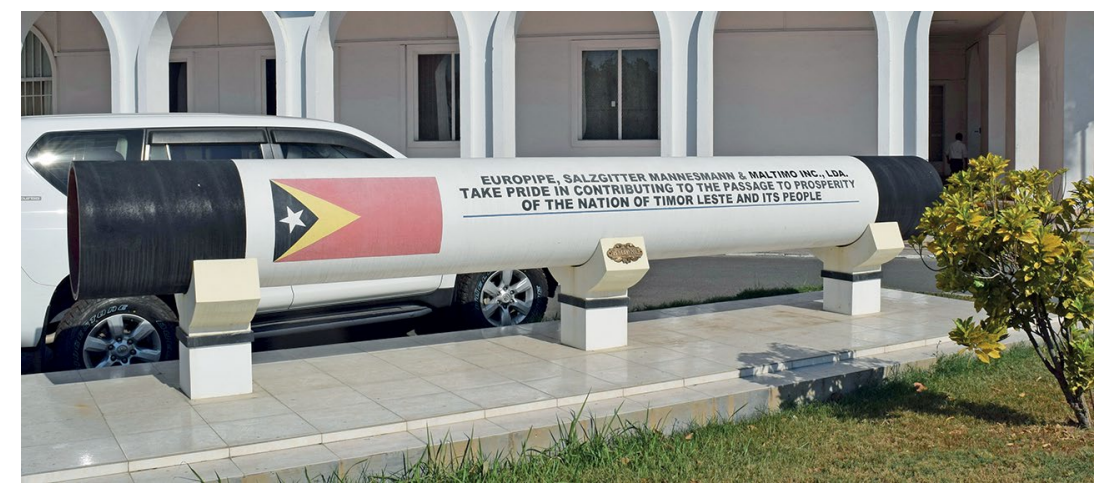

Figure 6.2. Sample pipeline in front of the Palácio do Governo in Dili. Source: Photo taken by author in August 2016.

The East Timorese Government commissioned their own study into the feasibility of a pipeline from Greater Sunrise to Timor-Leste's south coast. This included commissioning a sample pipeline constructed by Europipe, which now stands in front of Timor-Leste's government office (see Figure 6.2). Printed on the outside of the pipe, it says in English that the producers of the pipe 'take pride in contributing to the passage to prosperity of the nation of Timor-Leste and its people'. The 'documentthrowing' incident was not just about who would benefit economically from the Greater Sunrise oil and gas fields, valued at several billion dollars,

4 Despite having reached the landmark agreement to settle the maritime boundary in March 2018, by the time this chapter was finalised for publication, no agreement had been reached about the location for the processing of LNG from Greater Sunrise. 
it was also closely enmeshed with the boundary dispute between Australia and Timor-Leste. The document-throwing incident and, later, spying allegations are seen as matters of both national resource sovereignty and the sovereignty of Timor-Leste's national borders. The Tasi Mane project is connected to the question of the pipeline because it is partly based on the idea of producing LNG from Greater Sunrise onshore, in Beaço. The project, like the pipeline, centres on the idea that Timor-Leste itself should be involved in benefiting from the extraction and processing of its natural resources.

In March 2015, a debate ensued on Facebook. An American-educated academic based in Dili had allegedly said to a reporter that Timor-Leste would not be the next Singapore as the country was not strategically located. The vision of Singapore had been prominent in relation to infrastructure construction plans, including the Tasi Mane project. The comment appeared in print and outraged many, including a prominent Timorese politician, who posted an angry comment asking, 'Did anyone in Timor-Leste ever dreamed [sic] loud to be another Singapore?' Comments by other Facebook users strongly condemned the academic (who may well have been quoted out of context), expressing a very sincere sense of frustration that I think is symptomatic of a wider sentiment in the country. Saying Timor-Leste will not be the next Singapore was understood by some to mean that Timor-Leste is not allowed to envisage a prosperous future for itself. Some commentators asked why they, as East Timorese, were not allowed to dream and have ambitious plans. After all it was precisely the unrelenting ability to imagine a different future (one independent from Indonesia) that was such a motivating vision during the resistance struggle. The fact the Timor-Leste had regained independence was interpreted as evidence that dreams can come true. The comments revealed an intense dissatisfaction with the continuous dependence on foreign advisers and experts in both politics and the development industry. They also exposed a strong irritation at the negative assessments of TimorLeste's future by the outside world. Social media platforms allowed people to counter occidentalist representations and thus served to invigorate resource nationalism.

A very different kind of debate ensued on Facebook in August 2016 about a newspaper article citing the prime minister at the time, Rui Maria de Araújo, who addressed an audience of academics at the national university by asking 'in 15 years from now, can we be like Singapore?' Interestingly, the social media response was again critical. Rather than reaffirming their 
right to 'dream', commentators mocked the prime minister. One of the biggest points of critique was the suggestion that Timor-Leste would want to become like another nation, rather than developing its own specific trajectory. 'Why don't we have our own dream?', was one of the comments. What is really interesting about the two debates is that the response differed based on the identity of the person making the initial remark. A foreigner saying Timor-Leste would be no Singapore caused outrage, yet when the prime minister encouraged his audience to have precisely this dream, people mocked him and urged him to be realistic. It might also be worth noting that the article also stated that the prime minister had insisted that the country must diversify, and should not only rely on income from oil and gas - an aspect mainly neglected in the commentaries on social media.

In the classic anthropological study of the Venezuelan state from the perspective of oil booms and busts, Fernando Coronil (1997) effectively examined the interactions of national and international political struggles and how they have shaped the way Venezuelan governments managed the country's oil resources. In Venezuela's nationalist imaginary, the state became the unifying agent of the nation, which would act as the guardian of the country's oil wealth. The idea was that, through its oil wealth, the state would be able to magically bring about a prosperous and diversified society, hence Coronil's notion of the 'magical state'. In addition to his fine analysis of the internal political struggles connected to this imaginary, Coronil critically examined how the state might be dominant within the Venezuelan context, though in the global system it remains economically and politically marginal and dominated through notions of occidentalism.

'Occidentalism', according to Coronil (1997: xi), refers to the representational practices that portray non-western peoples as the 'Other' of the western self. His book develops 'a perspective from which to view societies that are central to the formation of what has been called the modern world and yet are cast as marginal to it' (ibid.). My argument is that East Timorese resource nationalism is not just a response to geopolitical inequalities that made it difficult for the government to negotiate a fair agreement over borders and resources for so many years. It is also a response to discursive practices of occidentalism that deny Timor-Leste the ability to govern its own resources. This became clear in a comment by a Timorese politician, who said he was told by an 
Australian counterpart in 2015 - off the record - that Australia would not give in regarding the maritime boundary, because Timor-Leste would just 'squander the money anyway'. As Coronil (1997: 14) put it:

While any society may produce stereotypical representations of cultural difference as part of its own self-production, what is unique about Occidentalism is that it entails the mobilisation of stereotypical representations of non-Western societies as part of the West's selffashioning as an imperial power. Occidentalism is inseparable from Western hegemony not only because it establishes a specific bond between knowledge and power in the West.

\section{Crude domination}

The second mode of domination that characterises resource nationalism in Timor-Leste is what Reyna and Behrends (2008: 11) call 'crude domination' - namely, the internal dynamic between different local and national actors seeking to assert control over profits from natural resources. Local struggles largely manifest themselves in concerns about the loss of land, and conflicts emerging from money received through government compensation. Landowners expressed deep concern about the fact that they would only receive US $\$ 3$ per square metre of land that they gave up for the Tasi Mane project. Arguments were made that the land prices had gone up to between US $\$ 4$ and US $\$ 15$ per square metre, depending on where the land was located, so they would struggle to buy land for the same price (see also Crespi and Guillaud 2018). It is also questionable whether financial compensation is really the best form of compensation for loss of land, because such cash injections can produce conflicts between or among families and do not necessarily provide people with livelihood security in the long term.

While interviewing residents affected by the Tasi Mane project in Suai, I was repeatedly told by local residents that they felt they simply did not have a choice. Hakarak ka lakohi ('whether we want to or not'; which might be more loosely translated as 'like it or not') was a sentence that I heard over and over again from people we interviewed: 'Whether we want to or not, we need to give our land' or 'Whether we want to or not, the project will go ahead anyway' (see also Almeida, Chapter 5 for Oecusse). Quite a few residents worried that the project might have potentially negative consequences. However, they had a sense that there was nothing they 
could do; the development would go ahead anyway. Hence, symptomatic of the domination of oil, their strategy was to get as much out of the government as they could (mainly in terms of monetary compensation for land). Some residents of Covalima I spoke to had received US $\$ 10,000$, US $\$ 15,000$ or, more rarely, even US $\$ 60,000$ in compensation for their land (US\$3 per square metre). Some had made good investments and bought land elsewhere, others did not and the problem of livelihood insecurity was an issue raised by many as a potential future problem.

During a 'socialisation' in 2015, participants also expressed concerns about the possible environmental impact the highway and accompanying pipeline may have (a pipeline is to lead from Suai to Betano alongside the highway). After TimorGap representatives explained some of the health and safety risks of the construction work, including fire risk, members of the affected community asked: 'How will you be dealing with the environmental problems if they occur on our land?' Local residents were also concerned about trees that would be cut down for the building project. People worried about losing their livelihood and not receiving adequate compensation. There were also concerns about access to water, especially if the highway cut people off from water resources. Locals were also concerned about how many of those working for the project would be local, and what percentage of workers would be foreigners. There were questions about how to deal with sacred (lulik) sites in the area designated for development, and how places where crocodiles (considered to be lulik) reside would be affected.

Although government officials and TimorGap employees clearly took into account the important cultural value of certain sites and were open to discuss how people's losses could be compensated, both financially and through the appropriate rituals, some research participants from the oil industry that I interviewed also suggested people were suddenly overvaluing sites of customary significance in order to increase benefits to themselves. There was a sense, by some of those charged with implementing the project, that people were invoking culture for economic gain.

The concerns of people attending the 'socialisations' are reflected in some of the critical literature on the project and in critiques formulated by a number of non-governmental organisations working in Timor-Leste (e.g. La'o Hamutuk 2011; Fundasaun Mahein 2013). Meabh Cryan (2015: 8-12), for example, stressed the potential negative impacts of the Suai Supply Base, including landlessness, homelessness, increased vulnerability of 
specific groups that are already vulnerable, impacts on gender equality, food insecurity, loss of livelihoods, joblessness, marginalisation and increased political and economic inequality. This echoes the possible problems Laura Meitzner Yoder (2015) identified with the plans to develop a special economic zone in the enclave of Oecusse, which, she argued, focus largely on the coastal regions and are designed to cater to foreigners, leaving rural populations in the highland marginalised and excluded from development. This echoes my own observation in Suai, where risks of joblessness, greater inequality, changed gender relations and potential for social envy and conflict seemed to be pertinent problems in the making.

Spokespeople for the Tasi Mane project promised economic development and employment opportunities to local people. And yet critics have argued that there is little employment in the oil industry, that TimorLeste's oil and gas is running out and it is not worth spending so much on an infrastructure program such as this, until it is clear whether the pipeline from Greater Sunrise is actually going to Timor-Leste's shores. The government's argument against the latter point is that the pipeline would only come to Timor-Leste if the infrastructure is in place: hence the Tasi Mane project was, to an extent, represented as a pre-emptive plan designed to force Australia's hand.

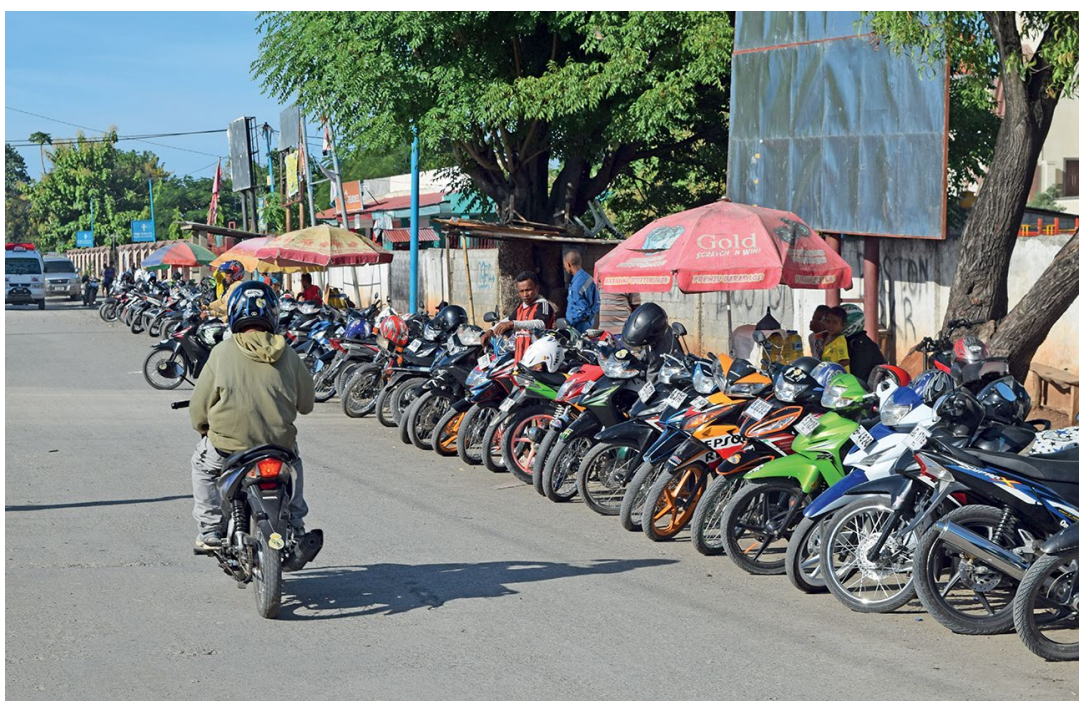

Figure 6.3. Motorbikes in Suai market.

Source: Photo taken by Mathijs Pelkmans in 2015, used with permission. 
In Suai, residents I spoke to joked, saying, 'in three years from now, people will be eating motorbikes'. This was a comment on the large numbers of motorbikes people had purchased with the money received in compensation for land. There were also reports of prices for land and food (vegetables, meat and other staple foods) having gone up rapidly in Suai since the compensation payments had been made and of people taking out loans on the basis of future compensation payments. There were worries people would spend the money they received rather than invest it in a more sustainable means of income for the future. There were also reports that some people had stopped pursuing some of the regular work they had been engaged in after having received money from compensation perhaps a symptom reminiscent of the resource curse, which is known to stifle productivity in non-oil-related sectors. There have also been criticisms that suggest the entire project is technically and financially unviable, that the project would destroy local cultural heritage and leave people landless with few prospects for the future. Supporters of the Tasi Mane project maintain that it is important to take some risks in order to produce benefits for everyone, and they expressed sincere worries that the criticisms voiced towards the project will end up scaring off investors.

In June 2015, a team from the government and from TimorGap travelled to Betano to present local residents with their plans to build an oil refinery there. A large tent had been erected in front of a house close to the sea, where small waves were gently splashing against the shores. The presentation of the refinery plans was quite similar to previous 'socialisation' events, and time was allowed for local residents to ask questions. As in previous meetings, most of the questions focused on issues relating to land ownership and the compensation schemes for loss of land. However, there was one question from a member of civil society, who asked the organisers about recent reports that Timor-Leste's oil and gas were running out as the Bayu-Undan field is close to depletion. (This was before the Boundary Treaty of 2018.)

The responses to what was a legitimate question at the time (see La'o Hamutuk 2015) were revealing. One of the leaders of TimorGap and a high-ranking member of the national government at the time argued that suggesting Timor-Leste's oil was running out was basically a false rumour spread by 'foreigners' - the goal of such rumours was to undermine Timor-Leste's struggle for resource sovereignty. References were made to the Australian spying scandal and those who criticised the Tasi Mane project were represented as anti-nationalist. The nationalist 
rhetoric representing the Tasi Mane development project as an extension of the resistance struggle was, in this case, used to deflect and perhaps even silence critics.

Despite some attempts to understand and connect with those affected by the Tasi Mane project, the project's representatives, responding to local people's questions, demanded their unwavering support. The audience was told that if people did not support the project, the government would take this fantastic scheme elsewhere and they would not get any benefits at all. With a sense of passion, the speaker from TimorGap at the Betano 'socialisation' responded to people's questions by saying: 'by 2020 we will no longer be importing gas or gasoline - you will be using your own gas and oil'. He added, 'You will not be hungry ... Your motorbike will always have petrol ... And we as a nation will no longer have to buy oil from foreign nations'. He then added:

At the moment, the government spends millions of dollars a year on buying petroleum from outside. When the pipeline is here, this money will go to you, because the government will no longer have to buy the petroleum from the outside ... This is why the state wants this project. It is about minimising the involvement of foreigners [estrangeiros].

Multiple references to the struggle for self-determination were made and the audience was asked to give up something for the good of the nation. Again, the nationalist rhetoric and the appeal to patriotic capitalism were very clear: the Tasi Mane project is represented as making TimorLeste independent from outsiders, thereby strengthening the country's sovereignty overall. Giving up their land was one of the sacrifices that people were asked to make.

During my research in Suai, I repeatedly heard from members of civil society that their attempts to establish a critical dialogue with affected community members about the development project and accompanying land dispossession were being thwarted. Some of them even felt intimidated and were critical of the prominent role veterans played in some of the developments and consultations. Critics also reported having been publicly admonished for warning against the negative consequences of oil dependency. One of the intended or unintended consequences of growing resource nationalism has been the attempt to sideline voices critical of megaproject development. 


\section{Conclusion}

For many East Timorese citizens, it would seem that dreams can indeed come true. In March 2018, Timor-Leste secured an agreement to create a permanent maritime boundary with Australia along the median line and confirmed a resource-sharing agreement that benefits Timor-Leste 70-80 per cent. This extraordinary achievement seemed impossible just a couple of years earlier. While this chapter was written prior to these recent events, in many ways they confirm the immense appeal and efficacy of Timor-Leste's resource nationalism discussed (for an analysis of the factors that led to the breakthrough in the negotiations with Australia, see Leach 2018).

This chapter has analysed the pertinence of resource nationalism in the contemporary political landscape of Timor-Leste. It has examined how the political discourse of resource nationalism conflates two issues: the issue of boundaries and the legitimacy and feasibility of onshore oil and gas infrastructure development. It has argued that 'struggles to dominate the flow of value produced by oil' (Reyna and Behrends 2008: 15) emerge out of the interlacing of national and international processes of domination. On the one hand, nationalist arguments are used internally to suppress critical voices of the Tasi Mane project; on the other hand, arguments about the dangers of oil dependency and profligate spending are used internationally to delegitimise Timor-Leste's legitimate claims to resource sovereignty. Occidentalist representations of East Timorese future visions intensify resource nationalism, which has thus far had limited success in connecting with campaigns for greater equality and social justice or in warding off aggressive market liberalisation. Yet, unlike in parts of Latin America, where in the past (during the time of high oil prices) resource nationalism has mitigated some of the more drastic impacts of the resource curse, in Timor-Leste, there is a risk that heightened nationalist sentiments around the issue of resource sovereignty could stifle more effective articulations of critique towards the ways in which oil profits are allocated internally. A disentangling of the issue of borders from the issue of onshore infrastructure development might allow more thorough scrutiny of contemporary development plans and thus ensure that the dream of resource sovereignty does not turn into a nightmare. 


\section{References}

Aditjondro. G. J. (1999) Is oil thicker than blood? New York: Nova Science Publishers.

Bovensiepen, J. and Meitzner Yoder, L. (2018) 'Introduction: Political dynamics and social effects of megaproject development' in Bovensiepen, J. and Meitzner Yoder, L. (guest eds), Megaprojects and national development models in TimorLeste, Special issue of The Asia Pacific Journal of Anthropology, vol. 19, no. 3, pp. 381-394. doi.org/10.1080/14442213.2018.1513553.

Coronil, F. (1997) The magical state: Nature, money, and modernity in Venezuela, Chicago and London: The University of Chicago Press.

Crespi, B. and Guillaud, D. (2018) 'Oil and custom: Impacts of the Tasi Mane oil project on the local communities in Suai, 2011-2017', in Bovensiepen, J. and Meitzner Yoder, L. (guest eds) Megaprojects and national development models in Timor-Leste, Special issue of The Asia Pacific Journal of Anthropology, vol. 19, no. 3, pp. 412-431. doi.org/10.1080/14442213.2018.1513060.

Cryan, M. (2015) Dispossession and impoverishment in Timor-Leste: Potential impacts of the Suai supply base, SSGM Discussion Paper 2015/15, Canberra: State, Society \& Governance in Melanesia, ANU. Available at: ssgm.bell school.anu.edu.au/sites/default/files/publications/attachments/2016-07/dp_ 2015_15-cryan.pdf.

Fundasaun Mahein (2013) 'Projetu Suai supply base: Dezenvolvimentu ka ameasa?' [The Suai supply base project: Development or danger?], Mahein Nia Lian Nú. 57, 29 August.

Gledhill, J. (2008) “"The people's oil”: Nationalism, globalization, and the possibility of another country in Brazil, Mexico, and Venezuela', Focaal: Journal of Global and Historical Anthropology, vol. 52, pp. 57-74. doi.org/ $10.3167 / \mathrm{fcl} .2008 .520104$.

La'o Hamutuk (2011) 'South Coast petroleum infrastructure project', La'o Hamutuk - The Timor-Leste Institute for Development Monitoring and Analysis, 16 September (updated 19 June 2016). Available at: www.laohamutuk.org/ Oil/TasiMane/11TasiMane.htm.

La'o Hamutuk (2015) 'Timor-Leste's oil and gas are going fast', La'o HamutukThe Timor-Leste Institute for Development Monitoring and Analysis, 15 April. Available at: laohamutuk.blogspot.co.uk/2015/04/timor-lestes-oil-and-gas-aregoing-fast.html. 
La'o Hamutuk (2016) 'Information about the treaty between Australia and Timor-Leste on Certain Maritime Arrangements in the Timor Sea (CMATS)', La'o Hamutuk - The Timor-Leste Institute for Development Monitoring and Analysis, 1 August. Available at: www.laohamutuk.org/Oil/Boundary/CMAT Sindex.htm.

La'o Hamutuk (2018) 'The Timor-Leste-Australia Maritime Boundary Treaty', La'o Hamutuk - The Timor-Leste Institute for Development Monitoring and Analysis, 21 March. Available at: www.laohamutuk.org/Oil/Boundary/ Treaty/18TreatyArticleEn.htm.

Leach, M. (2013) 'Turbulence in the Timor Sea: Australia could benefit too from a renegotiation of the maritime boundary', Inside Story, 6 December. Available at: inside.org.au/turbulence-in-the-timor-sea/.

Leach, M. (2018) 'Timor-Leste: Architect of its own sunrise', Inside Story, 8 March. Available at: insidestory.org.au/timor-leste-architect-of-its-ownsunrise/.

McGrath, K. (2014) 'Oil, gas and spy games in the Timor Sea. Australian scheming for the Greater Sunrise oilfield has a long history', The Monthly, April. Available at: www.themonthly.com.au/issue/2014/april/1396270800/kimmcgrath/oil-gas-and-spy-games-timor-sea.

McGrath, K. (2017) Crossing the line: Australia's secret history in the Timor Sea. Carlton: Redback.

Meitzner Yoder, L. S. (2015) 'The development eraser: Fantastical schemes, aspirational distractions and high modern mega-events in the Oecusse enclave, Timor-Leste', Journal of Political Ecology, vol. 22, pp. 299-321. doi.org/10.2458/v22i1.21110.

Reyna, S. and Behrends, A. (2008) 'The crazy curse and crude domination: Toward an anthropology of oil', Focaal: European Journal of Anthropology, vol. 52, pp. 3-17. doi.org/10.3167/fcl.2008.520101.

SDP (Democratic Republic of Timor-Leste) (2011) Timor-Leste strategic development plan 2011-2030. Available at: sustainabledevelopment.un.org/ content/documents/1506Timor-Leste-Strategic-Plan-2011-20301.pdf.

TimorGap (2015) Southern coast project. Available at: www.timorgap.com/ databases/website.nsf/vwAll/SOUTHERN\%20COAST\%20PROJECT. 
This text is taken from The Promise of Prosperity: Visions of the Future in Timor-Leste, edited by Judith Bovensiepen, published 2018 by ANU Press, The Australian National University, Canberra, Australia.

doi.org/10.22459/PP.2018.06 